\title{
Students' Perspective of Online Learning on Speaking Class During Covid-19 Pandemic
}

\author{
Yustina Fitriani ${ }^{1}$, Murti Bandung ${ }^{2}$, Mohtana Kharisma Kadri ${ }^{3}$ \\ ${ }^{1}$ yustina.fitriani@lecturer.itk.ac.id, ${ }^{2}$ murtibandung91@gmail.com, ${ }^{3}$ mohtana.kharisma@lecturer.itk.ac.id \\ ${ }^{1,3}$ Technology Institute of Kalimantan, ${ }^{2}$ Islamic and Religion Institute of Samarinda
}

\begin{abstract}
All educational institutions during COVID-19 pandemic move to online learning to prevent the spread of this virus. All students and lecturers of the institutions have no other option. They must use some of online platforms to continue the learning process. The aim of this research was to know the students' perspective of online learning on speaking class during COVID-19 pandemic. This research was categorized as mixed method research. There were 20 items of the questioner that have been distributed. The result showed that 14 items disagree and 6 items agree.
\end{abstract}

Keywords: online learning, speaking, COVID-19

\section{INTRODUCTION}

CoronaVirus Diseases 2019 (Covid-19) pandemic currently occurring in Indonesia has an impact on education. To prevent the spread of this virus, the government implemented a policy to close all learning activities in educational institutions. The decree no 9 of 3 April 2020 of the Ministry of Health (Permenkes 9/2020) explained "Guidelines for the implementation of Social Distancing on a Large Scale (PSBB) for the Acceleration of the Covid-19 Management". Mulenga, Eddie M. \& Jose M. Marban (2020) also explained that online learning is a way of combating the spread of a communicable virus like COVID-19. Toquero (2020) also explained that students can follow the social distancing measure by closing all activities in schools, colleges, and universities. According to this, the educational institutions instructed that the learning process where the interaction between students and educators (face-to-face) as usual moves to online learning. It is also as an alternative way to do during this pandemic (Firman \& Sari, R.R, 2020). It means that the learning is carried out using the communication media such as computer, cell phone and internet connection.

The development of Information and Communication Technology (ICT) has a big impact on education in Indonesia, especially in the learning process. Shenoy Veena, Sheetal Mahendra \& Navita Vijay (2020) explained that technology has a key role in educating the future generations. Dewi (2019) also stated in her journal that Information and Communication Technology (ICT) can be applied in teaching and learning languages. It means that the learning process not only can be applied in the class (traditional learning) but also can be applied in 
online learning. Cakrawati (2017) explained that the language learning should not only occur in the classroom, technological devices can be used by teachers and students to facilitate language learning. Online technologies also ensure valuable sources as asynchronous for the language learners while practicing foreign language (Celikbas 2018.p.133)

Based on the Ministry of Education regulation number 36962/MPK.A/HK/2020 about online learning and work from home in preventing CoronaVirus Diseases, it states that during the Covid 19 all institutions should enforce online learning from home for students (points 4 (a)). Based on this regulation, educators must use online learning platforms to facilitate students such as Zoom Cloud Meeting, Google Meet, Cisco Webex, etc.

Online learning is considered to be the best solution for teaching and learning activities in the midst of the COVID-19 pandemic. Even though it has been agreed upon, this study has caused controversy. For the teaching staff, online learning is only effective for assignments, while making students understand online learning material is considered difficult. In addition, the technological and economic abilities of each student are different. Not all students have facilities that support online learning activities. Inadequate internet connection, unsupported devices, and expensive internet quotas are obstacles to online learning. However, learning must continue. Each education provider has their own policies in responding to this rule. Several higher education institutions provide internet quota subsidies to students for the implementation of online learning.

Although there are several higher education institutions in Indonesia that are ready to carry out online learning, the presence of COVID-19 pandemic shows that there are more higher education institutions that are not ready to implement an online learning system. For example, the use of online learning technology is still dominated by universities in big cities because of financial capacity and the availability of digital learning (e-learning) systems that are better than small institutions in rural areas. In addition, there are many educators who still have difficulty using online learning technology, whether using e-learning or other platforms from third parties such as Zoom Cloud Meeting, Google Classroom, and CloudX. It makes online learning take place only by giving assignments remotely without any feedback or interaction with students.

Based on the explanation above, the writers intend to know the students' perspective of online learning on speaking class during COVID-19 Pandemic.

Perspective is an internal process that has been recognized by individual when selected and regulated stimuli that come from outside (Sujarwo, Sukmawati, Akhiruddin, Ridwan \& Siradjuddin, 2020). On the other hand, Martono (2016) stated that perspective is way of looking 
a problem that occurs, or a certain point of view used in seeing a phenomenon. In addition Mooney, Knox, and Schacht (2007) stated perspective as a simple way in looking at the world.

In sociology itself, perspective is the assumption used to the object of sociological study. This assumption is a form of perspective in understanding the various symptoms that occur based on a person's belief in studying an object. However, in general perspective is a point of view that actually be interpreted as a personal way of assessing something that can be describe as verbally or in writing.

Online learning is a teaching and learning process that utilizes an internet connection and learning platforms. Ade Kusuma in La Ode Anhusadar described that online learning is a learning process that utilizes an information technology, in this case utilizing the internet as a method of information delivery, interaction, and facilitation (2020, p.86). On the other hand, Adijaya \& Lestanto also explained that online learning can be done in an easy way because it only relies on applications that are connected to the internet (2018, p. 106).

To continue the learning process during this pandemic, many online platforms that can be used, such as zoom, goggle classroom, goggle meet, Moodle, etc. The online platforms promote both inquiry based learning and independent learning since the online platforms facilitate interactions between teacher and students although they are not in the same room (Cakrawati, 2017:23).

Speaking is one of the four skills of English learning. It also becomes the most important skill because it is always used in daily conversation. Leong, Lai-Mei \& Seyedeh Masoumeh Ahmadi, 2017, p.35) also explained that speaking is the most important skill because it is one of the abilities that is needed to perform a conversation. Speaking is a crucial part of second language learning and teaching, it is an art of communications and one of 4 productive skills that must be mastered in learning foreign language (Bahadorfar, Maryam \& Reza Omidvar, 2014: 9)

According to Hornby (1995, p.826) speaking is making use of words in an ordinary voice, offering words, knowing and being able to use a language expressing one-self in words, and making speech. Speaking also is an interactive process of constructing meaning that involves producing, receiving and processing information (Brown, 2001). Furthermore, according to Horwitz (2008) speaking is the hallmark of second language learning.

There are some reasons for teaching speaking they are: 1) Speaking is a crucial part of second language learning and teaching; 2) The mastery of speaking skills in English is a priority for many second language or foreign language learners; 3) Our learners often evaluate their 
success in language learning as well as the effectiveness of their English course on the basis of how much they feel they have improved in their spoken language proficiency; 4) Oral skills have hardly been neglected in today's EFL/ESL courses (Bahadorfar, Maryam \& Reza Omidvar, 2014, p.9).

\section{RESEARCH METHOD}

This study employed mixed method design to collect qualitative and quantitative data together. As Creswell (2009) states that mixed methods utilizes the strength of both qualitative and quantitative research. To collect the data, the writers used random sampling technique. There were 20 items of questionnaire distributed to 83 participants randomly selected in nonEnglish department students to get a quantitative data. The results were analyzed to determine the students' perspective of online learning on speaking class during COVID-19. The data were obtained using the four points of Likert's Scale: 1 for strongly disagree, 2 for disagree, 3 for agree, 4 for strongly agree. Suharto (2006, p.52-53) stated that the large of the score can be used to create score conversion by dividing the range with the objected class intervals.

\section{FINDINGS AND DISCUSSION}

In The data analysis results of students' responses are described below.

Table 1. Students' response in understanding the materials

\begin{tabular}{|c|l|c|c|}
\hline No. & \multicolumn{1}{|c|}{ Question } & $\%$ & Category \\
\hline 1 & $\begin{array}{l}\text { Online learning helps me understanding the } \\
\text { learning materials more easily }\end{array}$ & 48.8 & Disagree \\
\hline
\end{tabular}

Referring to the Table 1, $48.8 \%$ of the participants said disagree. They thought that online learning did not help them easily in learning the materials. It means that face-to-face learning in the classroom allows them to understand the materials easily.

Table 2. Students' response in motivation

\begin{tabular}{|c|l|c|c|}
\hline No. & \multicolumn{1}{|c|}{ Question } & Category \\
\hline 2 & $\begin{array}{l}\text { Online learning motivates me to study more } \\
\text { diligently }\end{array}$ & 48.8 & Disagree \\
\hline
\end{tabular}

The result shows that $48.8 \%$ of the participants said disagree. It means that online learning did not motivate them to study more diligently. It is because some of them find some difficulties in online learning, such as boring, no interaction, and no feedback directly, etc. 
Table 3. Students' response of the activeness in speaking

\begin{tabular}{|c|l|c|c|}
\hline No. & \multicolumn{1}{|c|}{ Question } & Category \\
\hline 3 & $\begin{array}{l}\text { Online learning encourage me to be more } \\
\text { active in speaking }\end{array}$ & 50.0 & Disagree \\
\hline
\end{tabular}

Based on the table above, it shows that $50.0 \%$ of the participants tended to choose disagree. Some students felt they cannot focus on the speaking practice. It is due to an unstable network connection and no interaction directly. So, they more prefer to only be a listener and be more passive.

Table 4. Students' response to self-confidence

\begin{tabular}{|c|l|c|c|}
\hline No. & \multicolumn{1}{|c|}{ Question } & $\%$ & Category \\
\hline 4 & $\begin{array}{l}\text { I feel comfortable to answer the questions } \\
\text { given in online learning }\end{array}$ & 62.2 & Agree \\
\hline
\end{tabular}

As described above, $62.2 \%$ of the participants feel comfortable to answer the questions given in online learning. It is because the lecturer used a video conference to call the students one by one, so that the students were not embarrassed to the others if they cannot answer the questions. Also, they have an opportunity to get feedbacks directly.

Table 5. Students' response in online learning and traditional learning

\begin{tabular}{|c|l|c|l|}
\hline No. & \multicolumn{1}{|c|}{ Question } & $\%$ & Category \\
\hline 5 & $\begin{array}{l}\text { I prefer to choose online learning rather than } \\
\text { traditional learning in the class }\end{array}$ & 50.0 & Disagree \\
\hline
\end{tabular}

The data of the table above shows that $50.0 \%$ of the participants disagree on the questions. Online learning is only the second choice that must be applied during covid-19 pandemic. They thought that it is better to study in the classroom as usual.

Table 6. Students' response to interest in learning

\begin{tabular}{|c|l|c|l|}
\hline No. & \multicolumn{1}{|c|}{ Question } & $\%$ & Category \\
\hline 6 & $\begin{array}{l}\text { Online learning has a great contribution to } \\
\text { my interest in learning }\end{array}$ & 53.7 & Disagree \\
\hline
\end{tabular}

Table 6 indicates that $53.7 \%$ of the participants said disagree. It means that the online learning does not contribute significantly to students' interest. They felt bored to study alone at home because there is no discussion or sharing information directly. 
Table 7. Students' response to find the learning needs

\begin{tabular}{|c|l|c|l|}
\hline No. & \multicolumn{1}{|c|}{ Question } & $\%$ & Category \\
\hline 7 & $\begin{array}{l}\text { Online learning eases me to find my learning } \\
\text { needs }\end{array}$ & 45.1 & Disagree \\
\hline
\end{tabular}

The result explains that $45.1 \%$ of the participants chose disagree. It means that online learning did not ease them to find the learning needs. Students need to share or discuss directly to their lecturer and friends. Not all students understand about what they have read. Sometimes they need more clarification and explanation toward the materials given by the lecturer.

Table 8. Students' response to overcome the learning problem

\begin{tabular}{|c|l|c|c|}
\hline No. & \multicolumn{1}{|c|}{ Question } & $\%$ & Category \\
\hline 8 & $\begin{array}{l}\text { Online learning eases me to overcome my } \\
\text { problem in learning }\end{array}$ & 43.9 & Disagree \\
\hline
\end{tabular}

Item 8 explains that $43.9 \%$ of the participants said disagree on the question. It means that online learning did not ease them to overcome their problem in learning. To overcome the problem, students need motivation from their friends. They need sharing learning materials each other and discussing about difficult materials together.

Table 9. Students' response to speaking improved

\begin{tabular}{|c|l|c|c|}
\hline No. & \multicolumn{1}{|c|}{ Question } & Category \\
\hline 9 & $\begin{array}{l}\text { Online learning environment enhances my } \\
\text { speaking skill }\end{array}$ & 46.3 & Disagree \\
\hline
\end{tabular}

The data shows that $46.3 \%$ of the participants tended to choose disagree. This means that the learning environment provided by lecturer does not attract their learning interest so that it does not help them in improving their speaking skill.

Table 10. Students' response to online speaking class

\begin{tabular}{|c|l|c|c|}
\hline No. & \multicolumn{1}{|c|}{ Question } & Category \\
\hline 10 & $\begin{array}{l}\text { English online class helps me in improving } \\
\text { my speaking skill }\end{array}$ & 47.6 & Disagree \\
\hline
\end{tabular}

Referring to the result of the questionnaire above, $47.6 \%$ prefers to choose disagree. It means that online speaking class does not help them in improving their speaking skill. They need to do a discussion or dialog in the class directly (face-to-face). It is more fun than doing a discussion only by a virtual conference. 
Table 11. Students' response to environmental influences

\begin{tabular}{|c|l|c|c|}
\hline No. & \multicolumn{1}{|c|}{ Question } & $\%$ & Category \\
\hline 11 & $\begin{array}{l}\text { The environment in online learning has a } \\
\text { huge influence on my speaking skills }\end{array}$ & 43.9 & Disagree \\
\hline
\end{tabular}

Based the table above, $43.9 \%$ comes from disagree of participants in e-Learning situation. It means that, e-learning environment were not good or the lecturers did not give more attention in the environment to make the students enjoy in the class.

Table 12. Students' response to environment in speaking class

\begin{tabular}{|c|l|c|c|}
\hline No. & \multicolumn{1}{|c|}{ Question } & $\%$ & Category \\
\hline 12 & $\begin{array}{l}\text { The environment in online learning makes } \\
\text { me difficult to study }\end{array}$ & 56.1 & Disagree \\
\hline
\end{tabular}

Item 12 has $56.1 \%$ of disagree which is means that some of the students were difficult in explore their ideas because of the environment is not providing them well. In addition, some conditions such as internet and incompetence students and lecturers in using media made this factors getting worse. That's why, we need to build a good environment during the class to make students enjoy in explore their ideas.

Table 13. Students' response to the effect of online learning

\begin{tabular}{|c|l|c|c|}
\hline No. & \multicolumn{1}{|c|}{ Question } & $\%$ & Category \\
\hline 13 & $\begin{array}{l}\text { The environment in online learning has an } \\
\text { effect on developing my ideas in speaking } \\
\text { class }\end{array}$ & 64.6 & Disagree \\
\hline
\end{tabular}

Side of item 12, this table showing that 64.6 disagree of this item because based on their mind; the environment did not give them an effect in improving their speaking skill. It means that, either the lecturer using good material or giving them time to explore but they could not more explore and it has been mention in item 12 .

Table 14. Students' response to the effect of online class in daily

\begin{tabular}{|c|l|c|c|}
\hline No. & \multicolumn{1}{|c|}{ Question } & $\%$ & Category \\
\hline 14 & $\begin{array}{l}\text { The environment in online learning affects } \\
\text { my daily routine of learning }\end{array}$ & 68.3 & Disagree \\
\hline
\end{tabular}

Referring to the table above, it seems like the previous table on 12 and 13. It means that the environment did not gave them affect during the class, which is even the material were good but if their environment did not provided well then could not affect more to their daily learning 
routine. That is why there are $68.3 \%$ disagree. To overcome the problem, they need a good environment in e-learning class to improving their skill.

Table 15. Students' response to learning style in speaking class

\begin{tabular}{|c|l|c|c|}
\hline No. & \multicolumn{1}{|c|}{ Question } & $\%$ & Category \\
\hline 15 & $\begin{array}{l}\text { The environment in online learning affects } \\
\text { my learning style }\end{array}$ & 74.4 & Disagree \\
\hline
\end{tabular}

Based on the table above, the data was higher than the previous table. It means that the environment in e-learning still as a main factor that need to improve. In addition, online class did not contribute significantly to students' learning style. They felt bored to study alone at home because there is no discussion or sharing information directly to their friends.

Table 16. Students' response to interaction between students

\begin{tabular}{|c|l|c|c|}
\hline No. & \multicolumn{1}{|c|}{ Question } & Category \\
\hline 16 & $\begin{array}{l}\text { Speaking classes in online learning make me } \\
\text { easier to interact with friends }\end{array}$ & 58.5 & Agree \\
\hline
\end{tabular}

The data that has been describe on table above explain that $58.5 \%$ were agree that online learning make them easier to interact with their friends. As we know because of corona virus, social distancing was implemented to stop the virus. It means that, the students have been three or four months did not meet their friends. So, by online class they were happy to interact each other.

Table 17. Students' response to interaction to lecturer

\begin{tabular}{|c|l|c|c|}
\hline No. & \multicolumn{1}{|c|}{ Question } & $\%$ & Category \\
\hline 17 & $\begin{array}{l}\text { Speaking classes in online learning make me } \\
\text { easier to interact with lecturers }\end{array}$ & 54.9 & Agree \\
\hline
\end{tabular}

On the table above, there is 54.9 Agree that speaking classes in online learning make them easier to interact with the lecturers. Possibility comes from students who are unable to express their ideas in face to face class.

Table 18. Students' response to method in speaking class

\begin{tabular}{|c|l|c|c|}
\hline No. & \multicolumn{1}{|c|}{ Question } & $\%$ & Category \\
\hline 18 & $\begin{array}{l}\text { Speaking classes in online learning are more } \\
\text { fun than face-to-face }\end{array}$ & 46.3 & Agree \\
\hline
\end{tabular}

From the data table above, there are $46.3 \%$ who agree that speaking classes in online learning are more fun than face-to-face. It shows that table 17 is answered in this table. It means 
that, there are some students who find it difficult to express or share their ideas during discussion in face-to-face class, but they enjoy in online learning.

Table 19. Students' response to approaches in speaking class

\begin{tabular}{|c|l|c|c|}
\hline No. & \multicolumn{1}{|c|}{ Question } & $\%$ & Category \\
\hline 19 & $\begin{array}{l}\text { Speaking classes in online learning make me } \\
\text { more active in group discussions }\end{array}$ & 48.8 & Agree \\
\hline
\end{tabular}

The data above shows $48.8 \%$ agree that the speaking class in online lectures makes me more active in group discussions. This showed that students who are less active during face-toface class are able to express their ideas in a discussion. It means, online class helped some of them to overcome their barrier in expressing their mind.

Table 20. Students' response to speaking class

\begin{tabular}{|c|l|c|c|}
\hline No. & \multicolumn{1}{|c|}{ Question } & $\%$ & Category \\
\hline 20 & $\begin{array}{l}\text { There is no difference between online } \\
\text { learning and face-to-face lectures. }\end{array}$ & 45.1 & Agree \\
\hline
\end{tabular}

Different from some of the previous items, there are $45.1 \%$ who agree that there is no difference between online learning and face-to-face lectures. It means that they enjoy every learning process both online and offline.

\section{CONCLUSION}

Based on the findings of the study, 14 items from 20 items shown disagree. It means that most of the students said disagree. It is because the online learning did not help them in improving their speaking skill. Some of the problems come from the internet connection, available devices, students' data, and some of them also want to share their idea in the class directly (face-to-face situation). In another hand, the students are more comfortable to study in offline class rather than online class. It is because the learning environment more interesting. In this case, it comes from how the lecturer provides the learning materials and learning atmosphere. However, there are 6 items shown agree. It means that some of them are introvert students and prefer to choose online class because their lecturer used a video conference to call them one by one in speaking class so that they were not embarrassed to express their idea. Hence, they enjoy the learning class and there is an effect in improving their speaking skill. In this way, the lecturer should consider students situation in terms of internet connection, available devices, students' data (credit unit), and using an appropriate technique. 


\section{REFERENCES}

Adijaya, Nuryansyah \& Lestanto, P.S. (2018). Persepsi Mahasiswa dalam Pembelajaran Online, $10(2), 105-110$.

Anhusadar, La Ode. (2020). Persepsi Mahasiswa PIAUD terhadap Kuliah Online di Masa Pandemi Covid 19, 3(1), 44-58.

Bahadorfar, Maryam \& Reza Omidvar. (2014). Technology In Teaching Speaking Skill. Acme International Journal of Multidisciplinary Research, 2, 9-13.

Brown, H. Douglas. (2001). Teaching by Principles: An Interactive to Language Pedagogy. San Francisco: Addison Wesley Longman.

Celikbas, Selin. (2018). The Effectiveness of Online Conversation Classes through the Use of Adobe Connect Live Learning Program. Journal of Foreign Language Education and Technology, 3(1), 130-147.

Dewi, Puspita. (2019). Teaching English for Young Learners through ICTS. Journal on Language and Literature, 6, 11-24.

Cakrawati, L.M. (2017). Students' Perceptions on the Use of Online Learning Platforms in EFL Classroom. English Language Teaching and Technology Journal, 1, 22-30.

Creswell, John. W. (2009). Research Design (Pendekatan Kualitatif, Kuantitatif, dan Mixed). Yogyakarta: Pustaka Pelajar.

Firman \& Sari, R.R. (2020). Pembelajaran Online di Tengah Pandemi Covid-19. Indonesian Journal of Educational Science (IJES), 02, 81-89.

Hornby. (1995). Advanced Learners Disctionary. New York: Oxford University.

Leong, Lai-Mei \& Seyedeh Masoumeh Ahmadi. (2017). An Analysis of Factors Influencing Learners' English Speaking Skill. International Journal of Research in English Education, 34-41.

Martono, N. (2016). Sosiologi perubahan sosial: perspektif klasik, modern, posmodern, dan poskolonial. Raja Grafindo Persada Jakarta.

Mubaslat, Mania Moayad. (2012). Practical English Language Teaching PELT:Mc. Graw-Hill Singapore.

Mulenga, Eddie M. \& Jose M. Marban (2020). Prospective Teachers' Online Learning Mathematics Activities in The Age of COVID-19: A Cluster Analysis Approach

Mooney, Knox, \& Schacht. (2007). Undestanding social probel, $5^{\text {th }}$ edition.

Shenoy Veena, Sheetal Mahendra \& Navita Vijay. (2020). COVID 19 - Lockdown: Technology Adaption, Teaching, Learning, Students Engagement and Faculty Experience. Mukt Shabd Journal, 9, 698-702.

Suharto, G. (2006). Penilaian Hasil Belajar Bahasa Inggris. Yogyakarta: P3B.

Sujarwo, Sukmawati, Akhiruddin, Ridwan \& Siradjuddin. (2020). An Analysis of University Students' Perspective on Online Learning in the Midst of Covid-19 Pandemic. Jurnal Pendidikan dan Pengajaran, 53 (2), 125-137. 
The decree no 9 of 3 April 2020. Guidelines for the implementation of Social Distancing on a Large Scale (PSBB) for the Acceleration of the Covid-19 Management. 9 April 2020. The Ministry of Health. Jakarta.

The decree no 36962/MPK.A/HK/2020. Online learning and work from home in preventing CoronaVirus Diseases. 2020. 4 (a)). The Ministry of Education. Jakarta.

Toquero, C.M. (2020). Challenges and Opportunities for Higher Education Amid the COVID19 Pandemic: The Philippine context. Pedagogical Research, 5 (4), 1-5.

William, D. (2007). A unique review strategy that motivates students learning.Students motivation. Vol (2), 64-69. 
